proposed supplements to the recognition of irrevocable proxies, they should be considered in connection with any amendment of our voting trust statutes. The right to vote has long been considered one of the shareholders' strongest weapons against manipulation by corporate management. No arrangement which impairs such protection should be sanctioned without appropriate restraints.

\title{
JOINT INCOME TAX RETURNS UNDER THE REVENUE ACT OF 1948'
}

\section{INTRODUCTION}

One of the most important features of the Revenue Act of $1948^{1}$ is its provision permitting income splitting by married couples throughout the country. This is the latest step in the long struggle for tax equalization between community property and non-community property states. Though the criticisms have become more acute as the tax burden has increased, the history of the active protest goes back as far as $1921,{ }^{2}$ at which time the House passed a revenue bill ${ }^{3}$ requiring that community income be included entirely in the gross income of the spouse having management and control over such community income. This provision failed to obtaim the approval of the Senate, and it was not resurrected in conference. ${ }^{4}$ Similar unsuccessful attempts to attain tax equality through taxation of the community "manager" were made in $1924,{ }^{5} 1934,{ }^{6}$ and $1941 . .^{7}$

Another proposed approach to tax equality was through the medium of compulsory joint returns by husband and wife. Attempts along these lines were made in $1933,{ }^{8} 1934,{ }^{9} 1937,{ }^{10} 1941,{ }^{11}$ and $1942 .{ }^{12}$ But

+ Contributed by Spencer Williams, member of the third-year class.

1 Pub. L. No. 471, 80th Cong., 2d Sess. (April 2, 1948) over presidential veto.

2 For a detailed report of this history see: Hearings before Committee on Ways and Means on Community Property and Family Partnerships, Pt. 2, 80th Cong., 1st Sess. 852 (1947).

3 H. R. 8245, 67th Cong., 1st Sess. § 208 (1921).

4 Statement of the Managers of the House on Amendment 134, Conf. Rep. No. 486, Revenue Bill of 1921, 134.

5 Treasury Draft of the Revenue Act of 1924, $\$ 21$ (a).

- Hearings before a stb-committee of the Committee on Ways and Means on H.R. 8392, 73d Cong., 2d Sess. 6 (1934).

i H. R. 5417, 77th Cong., 1st Sess. $\$ 119$ (1941).

8 Statement of the Acting Secretary of the Treasury regarding the preliminary report of a Subcommittee of Ways and Means relative to methods of preventing the avoidance and evasion of the internal revenue laws . . , 15 (1933).

9 The proposal was dropped because of drafting difficulties. See letter dated Dec. 15, 1933 to L. H. Parker, Chief of Staff of the Joint Committee on Internal Revenue Taxation, reprinted in Hearings before a subcommittee of the Comnzittee on Ways and Means on Commentity Property Income, 73d Cong., 2d Sess. 24 (1934).

10 Hearings before the Joint Committee on Tax Evasion and Avoidance, Pt. 2. 75th Cong., 2d Sess. 309-313 (1937).

11 H. R. 5417, 77th Cong., 1st Sess. \$ 111 (1941). 
they "foundered before (1) the solid phalanx of sixteen complacent senators, and (2) the ignorance of most of the people in the rest of the country of the discrimination against them."13

With the Republican Party and Congress committed to tax reduction, widespread interest was directed at another plan of approach which would permit spouses in all states to divide equally their combined incomes, exemptions and deductions for income-tax purposes. ${ }^{14}$ The geographical tax equalization as to married couples will probably produce a result similar to that which would have obtained from compulsory joint returns. ${ }^{15}$ The 'split income' method of the Revenue Act of 1948 , however, was politically palatable since it gave tax reduction by an extension of a minority's tax minimization benefits to the majority. Thus, at long last, substantial equalization between community property and non-community property couples has been achieved. National and international commitments may well require revenue legislation that will wipe out the tax reduction features of the Revenue Act of 1948, but it is safe to predict that Congress will never reinstate ' the marked tax advantages of community property over non-community property states which formerly prevailed.

The income splitting feature was extended mainly through amendments to Internal Revenue Code sections 12,23 (aa) and 51 (b).$^{16}$ Subsection (d), added to section 12 , provides that where a husband and wife file a joint return, their net incomes and exemptions are divided by two, a preliminary tax computed thereon, and the result multiplied by two to obtain the final tax. ${ }^{17}$ Section 23 (aa)(1)(A) is amended to

12 Hearings before the Committee on Ways and Means on Revenue Revision of 1942, Vols. 1, 2, Revised, 77th Cong., 2d Sess. 10, 85, 1612 (1942).

13 Griswold, Cases and Materulas on Federal Taxation (2d ed. 1946) 428. Due "credit" must also be given to the opposition of wealthy non-community property husbands who had achieved income splitting advantages through gifts of income-producing property to members of their immediate families.

14 Hearings before the Conmittee on Ways and Means on Communily Properly and Family Partnerships, Pt. 2, 80th Cong., 1st Sess. 856 (1948).

15 See address by Stanley S. Surrey before the National Tax Association, June 4, 1946, reprinted in (1946) 24 TAxes 980: "Considered as a permanent system, as between married "couples at any level there appears to be little reason to prefer one method over the others. The tax in either case would be the same for every married couple at that level regardless of internal distribution of income .... Whether married couples would pay more dollars under a mandatory joint return system or under a per capital division depends almost entirely on the rate structure adopted after one or the other system is șelected."

16 Revenue Act of 1948 , Title III, Husband and Wife, Part I, Income Tax.

17 Revenue Act of 1948, §301 ; SEN. REP. No. 1013, 80th Cong., 2d Sess. 53 (1948): "The application of section 12(d) is illustrated by the following example in which $H$ is used to refer to the husband and $W$ is used to refer to his wife with whom a joint return is filed for the calendar year 1948. $H$ has a salary of $\$ 8,000$ for 1948 and pays during 1948 local property taxes on his residence in the alnount of $\$ 100$ and medical expenses for himself and $W$ in the amount of $\$ 700 . W$ has income from 1948 from dividends of $\$ 2,000$ and during 1948 makes gifts to charitable organizations (deseribed in section 23(0) 
provide that the standard deduction for joint returns reporting incomes over $\$ 5000$ shall be $\$ 1000$ or $10 \%$ of the adjusted gross income, whichever is the lesser. ${ }^{18}$ To prevent married couples from securing a $\$ 2000$ standard deduction by filing separate returns, it is provided that when married persons file separate returns each is entitled to a deduction of only $\$ 500 .{ }^{19}$ The requirement that both husband and wife must use the standard deduction, if either is to use it, is retained. ${ }^{20}$ The requirement that husband and wife must be living together in order to take the standard deduction is deleted from section 23(aa) (4). This brings 23(aa)(4) into conformity with 51(b), which no longer requires that husband and wife inust be living together in order to file a joint return. Subsection (6), added to 23 (aa), ${ }^{21}$ provides that determination of status shall be inade at the close of the taxpayer's taxable year, or, if his spouse dies, at the time of death. It further provides that an individual legally separated from his spouse under a decree of divorce or of separate maintenance shall not be considered

of the code) in the amount of $\$ 1,600 . H$ and $W$ are not entitled to any exemptions other than the personal exemption of each. The tax on the joint return of $H$ and $W$ for 1948 is $\$ 1,244.80$ determined as follows:

1. Salary . • . • . . • . . . . . . . \$\$,000.00

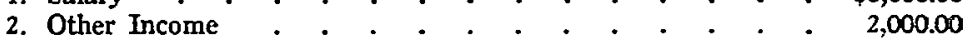

3. Adjusted gross income . . . . . . . . . . 10,000.00

4. Deductions:

(a) Charitable contributions (limited to $15 \%$ of adjusted gross income) . . . . . . $\$ 1,500$

(b) Taxes $\quad \cdot \quad \cdot \quad \cdot \quad \cdot \quad \cdot \quad \cdot \quad \cdot \quad \cdot \quad 100$

(c) Medical expenses (in excess of $5 \%$ of adjusted gross income sec. $23(x)$ of the code); excess of $\$ 700$ over $5 \%$ of $\$ 10,000 . \quad . \quad . \quad . \quad . \quad . \quad 200 \quad 1,800.00$

5. Net income . . . . . . . . . . . . . . $8,200.00$

6. Net income reduced by one-half . . . . . . . . . . $\quad$. 4,100.00

7. Credits against net income under sec. 25 ( 2 personal exemptions under sec. 25 (b) (1) (A) of the code as amended in this bill)

8. Credits in item 7 reduced by one-half . . . . . .

9. Net income reduced by one-half (item 6 ) minus credits reduced by one-half (item 8 )

10. Tentative normal tax computed under sec. 11 of the code on amount in item $9(3 \%$ of $\$ 3500)$. . . . . . . .

11. Tentative surtax computed under sec. $12(\mathrm{~b})$ on the amount in item 9 ( $\$ 340$ plus $19 \%$ of excess of $\$ 3,500$ over $\$ 2,000$ ).

12. Aggregate of tentative normal tax and tentative surtax .

13. Combined normal tax and surtax determined under section 12 (c) of the code ( $\$ 730$ reduced by $\$ 68$ plus $12 \%$ of the excess of $\$ 730$ over $\$ 400$ )

105.00

625.00

730.00

622.40

14. Twice the combined normal tax and surtax determined in item 13 . . . . . . . . . . . . . . $1,244.80$

18 Revenue Act of 1948, § 302 (a).

19 Ibid.

$20 \mathrm{Id}$. 302 (b).

21 Id. $\$ 302(\mathrm{c})$. 
married. The rule is derived from $22(\mathrm{k}),{ }^{22}$ and sections $25(\mathrm{~b})^{23}$ and $51(\mathrm{~b})^{24}$ are also amended to conform. The committee reports which accompanied this bill stated that uniform construction is intended for all of these sections. ${ }^{25}$

The joint return section, 51(b), has been extensively revised. ${ }^{20}$ It disqualifies from joint returns those who "at any time" during the taxable year were non-resident aliens, ${ }^{2 \pi}$ requires that spouses must have the same taxable year, ${ }_{2}^{28}$ but makes an exception that the death of one spouse shall not deprive the surviving spouse, otherwise eligible, from filing a joint return. If a surviving spouse remarries during the taxable year of his spouse's death, he may not file a joint return with the deceased spouse. He may, however, file a joint return with his new spouse if the other requirenuents of 51 (b) are met. ${ }^{20}$ Section 51 (b) (4) provides in detail how a joint return is to be made after the death of a spouse. ${ }^{30}$ The medical deductions of $23(\mathrm{x})$ are extended for joint returns. The maximum deduction on separate return for a person without dependents is still $\$ 1250$, and $\$ 2500$ where there are

22 H. R. REp. No. 1274, 80th Cong., 2d Sess. 45 (1948) ; SEN. Rep. No. 1013, 80th Cong., 2d Sess. 50, 52 (1948).

23 Revenue Act of $1948, \S 201$.

24 Id. $\$ 303$.

25 H. R. REP. No. 1274, 80th Cong., 2d Sess. 45 (1948); SEN. REp. No. 1013, 80th Cong., 2d Sess. 50, 52 (1948).

28 Revenue Act of 1948, $\$ 303$.

${ }_{27}$ INT. Rev. CoDE $\$ 51(\mathrm{~b}) 2$.

$28 I d$. $\$ 51$ (b) 3 .

29 Ibid., SEv. Rep. No. 1013, 80th Cong., 2d Sess. 56 (1948).

30 Ser. Rep. No. 1013, 80th Cong., 2d Sess. 56 (1948). Paragraph (4) apphics both to cases where the death of one spouse closes his taxable year and also to cases where one dies after the close of the taxable year but before his return is filed. Generally the joint return for a deceased spouse may be made only by his duly appointed executor or administrator. However, if (1) no return has been made by the decedent for tbe taxable year in question, (2) no executor or administrator has been appointed at or before the time of making the return, and (3) none is appointed before the last day prescribed by law for filing the return of the surviving spouse, then the surviving spouse may make a joint return for himself and the deceased spouse. Where one spouse, of a couple filing on a calendar-year basis, dies between January first and March fifteenth, joint returns may be made both for the preceding taxable year, and for the year of death, if the conditions set forth above are satisfied with respect to each return. If the surviving spouse makes the joint return provided for above, an executor or administrator thereafter appointed may disaffirun such joint return within one year after the last day prescribed by law for filing the return of the surviving spouse. It must be made in the form of a separate return for the taxable year of the decedent with respect to which the joint return was made. In the event of such disafirmance, the joint return made by the survivor shall be treated as his separate return and the tax thereon shall be computed by excluding all items properly includible in the return of the deceased spouse. The separate return made by the executor or administrator shall constitute the return of the deceased spouse for the taxable year. It should be noted that the time allowed the executor or administrator to disaffirm the joint return is not intended to establish a new due date for the return of the deceased spouse. As a result, the provisions of $\$ \$ 291$ and 294 relating to delinquent returns will be applicable. 
two exemptions. A maximum of $\$ 2500$ is allowed on a joint return where there are two exemptions, $\$ 3750$ where there are three and $\$ 5000$ where there are four or more exemptions. ${ }^{31}$ The Revenue Act of 1948 is applicable to calendar tax years which begin after December 31,1947 , and to fiscal years which began in 1947 and end in $1948 .^{32}$

In computing the capital gains tax under section 117 (b), 50\% of the long term capital gain is taken into account as formerly and added to other income to arrive at the net income, which is then divided in half ${ }^{33}$ for tax computation. If the alternative capital gains tax under section 117 (c) (2) is used, the partial tax is computed without regard to the capital gain, and $25 \%$ of the capital gain ${ }^{34}$ is added to the partial tax to determine the total tax. ${ }^{35}$

\section{RELATIVE ADVANTAGES OF JOINT RETURN AND SEPARATE RETURNS}

\section{A. Advantages of Using the Joint Return.}

The advantage of splitting income formerly extended only to community income. A spouse who received separate income was required to report all such separate income on his own return. ${ }^{36}$ Through use of the joint return all income may now be aggregated, and then divided $^{37}$ For the first time California spouses will be able automatically to split their separate imcomes. ${ }^{38}$ Thus the joint return may bring material tax advantages to California families, especially where a substantial part of the family income is derived from separate property ${ }^{39}$

Another outstanding advantage of the joint return now available without tax detriment to community property couples comes from the right to offset capital losses of one spouse against the capital gains of the other, and their right to aggregate deductions and exemptions. Though the regulations were formerly contra, it is now well settled

31 Revenue Act of 1948, § 304; SEN. REP. No. 1013, 80th Cong., 2d Sess. 58 (1948).

32 Revenue Act of $1948, \$ 305$.

33 See note 17 supra.

$3450 \%$ of the excess of the net long term capital gains taken into account over the short term capital losses.

35 SEN. REP. No. 1013, 80th Cong., 2d Sess. 54 (1948). It is now more advantageous to use the alternative tax where the net income less exemptions exceeds $\$ 22,000$ on a separate return, or $\$ 44,000$ on a joint return.

30 Lucas v. Commissioner of Internal Revenue (C. C. A. 5th 1943) 134 F. (2d) 319.

37 Revenue Act of 1948, §301; INT. REv. CODE § 12(d).

38 Sen. REp. No. 1013, 80th Cong., 2d Sess. 24, 25 (1948).

39 For example, if a hushand has $\$ 20,000$ salary and separate income of $\$ 10,000$, he would have filed for $\$ 20,000$ (one-half of the community income and all of his separate income) under the former law, and the wife would have reported $\$ 10,000$. Under the Revenue Act of 1948 they may now file for $\$ 30,000$ on a joint return, which will result in a tax saving of approximately $\$ 1600$. 
that deductible losses sustained by either spouse may be offset against the gains or income of the other spouse. ${ }^{40}$

\section{B. Advantages of Using Separate Returns.}

Since spouses filing a joint return are taxed as a unit, the maximum capital loss deduction of $\$ 1000$ is applicable. ${ }^{41}$ Where both spouses suffer capital losses, a tax saving might be realized through separate returns, since each spouse may take capital losses up to $\$ 1000$ and still be able to split the community income.

It has been suggested that a tax saving may be realized through separate returns where one spouse has unusually large deductions measured by a percentage of the adjusted gross income. This rule seems applicable in community property states solely as to medical deductions, and then only when (1) the gross aggregate income is under $\$ 10,000$, (2) the spouses have separate incomes in addition to the community incone, and (3) the spouse paying the excessive amounts can sustain the burden of proving that the medical expenses are not community deductions but were paid out of separate income. ${ }^{49}$ Where any allowable deduction is computed as a straight percentage of gross income, as in charitable contributions, there will seldom be

40 That husband and wife may offset their capital gains and losses: Janney v. Commissioner of Internal Revenue, (1940) 311 U.S. 192; U.S. Treas. Reg. 111, $\$ 29.117-5$ (b) (1943) ; Note (1940) 53 Harv. L. Rev. 681; Cr. D. 1479, 1942-2 CuM. Bun. 220.

That deductions may be aggregated: Sox. Op. 90, 4 Cusr. Buxr. 236 (1921); Taft v. Helvering, (1940) 311 U.S. 195; CT. T. 1478, 1940-2 CuM. BuLx. 218.

41 INT. REv. Code $\$ 117$ (d) 2; Marvin L. Levy (1942) 46 B.T.A. 1145; L. L. Tweedy (1942) 47 B.T. A. 341.

42 C. C. H., Tax Reduction Revenue Act of 1948 with Explanation (April, 1948). For example, if the spouses have no separate incomes and medical expenses were paid out of community income, the deduction is divided. (See note 43 infra.) Thus if there is a $\$ \$ 7000$ adjusted gross community income and $\$ 1000$ medical expenses, a joint return will result in an allowable deduction of $\$ 650$ (the excess of $\$ 1000$ over $5 \%$ of $\$ 7000$ ). Separate returns will result in two $\$ 325$ (the excess of $\$ 500$ over $5 \%$ of $\$ 3500$ ) deductions. If, however, there is only $\$ 1000$ in conmunity income, and the husband and wife have separate incomes of $\$ 4500$ and $\$ 1500$ respectively, the result would be different. Assuming that the wife has $\$ 1000$ medical expenses and can prove that they were paid from her separate property, the deduction with a joint return would be $\$ 650$, while under separate returns total deductions would be $\$ 900$ (the excess of $\$ 1000$ over $5 \%$ of $\$ 2000$ ). Although the husband is moved up into the $\$ 5000$ income tax bracket, the greater allowable deduction will create some tax saving.

$\$ 3$ Ernest W. Clemens (1947) 8 T.C. 121 at 125: "It is well settled that spouses domiciled in a community property state may divide their community income equally in separate returns, and that deductions properly chargeable against such returns should be equally divided between the spouses, but where contributions are made by one of the spouses from his or her separate funds, such spouse is entitled to deduct them in full .... The burden, however, is on the spouse claiming the deduction to show by competent evidence that he or she is entitled to the deduction claimed .... The medical expenses were community expenses, payable primarily from community income . . . ." 
any larger deductions obtainable by the use of separate returns. ${ }^{44}$ And joint, rather than separate, returns will result in large charitable deductions when one spouse has made charitable contributions exceeding the amount deductible, while the other spouse has made no contributions or contributions less than the amount allowable for deduction.

\section{Some Continuing Community Property Tax Advantages.}

The income splitting provisions of the Revenue Act of 1948 were aimed directly at creating an equality between community property states and non-community property states. Though this was substantially achieved, there are several noticeable instances where community property states retain vestiges of their former advantage.

In non-community property states, married couples have but one automatic avenue of income splitting - the joint return. Where this route is not open, they must suffer the impact of a full tax to the income-earning spouse. In community property states, however, married couples have two methods by which they may split their income: (1) the new joint return method, and (2) the old commumity property method. Where one avenue of income splitting is blocked, or is disadvantageous, taxwise, the other avenue may still be open.

\section{Where one spouse is a non-resident alien.}

Section 51(b) (2) provides that no joint return may be filed if either spouse is a non-resident at any time during the taxable year. Thus a non-community spouse who has a non-resident alien spouse will be deprived of his split income advantage. ${ }^{45}$ The community prop-

\footnotetext{
44 Separate returns will create greater available charitable deductions only in situations where the adjusted gross income of one spouse is a minus quantity. (For example, suppose a husband with adjusted gross income of minus $\$ 10,000$, wife with an adjusted gross income of $\$ 12,000$. Under joint return, the aggregate adjusted gross income would be $\$ 2000$, with maximum allowable deductions of $\$ 300$. On separate returns, wife could take maximum allowable deductions of $\$ 1800$.) In these situations, however, greater over-all tax savings would result from a joint return since the wife could offset the husband's deductions against her income.

Where both spouses have incomes, the allowable charitable deductions will be the same whether income is allocated through separate returns or aggregated through a joint return. For example, if husband has income of $\$ 15,000$ and wife income of $\$ 5000$, the allowable charitable deduction on $\$ 20,000$ will be $\$ 300(15 \%$ of $\$ 20,000)$; on separate returns the allowable deductions will also total $\$ 300$ ( $15 \%$ of $\$ 15,000$, plus $15 \%$ of $\$ 5000$ ).

45 Altbough the terms "domicile" and "residence" are often used interchangeably, they are distinguished for purposes of ascertaining non-resident ahens. MERTENS, TrE LAW OF FEDERAI INCOAIE TAXATION $\$ 45.09$ (1942). Though the marital domicile of the wife generally follows the husband, a foreign woman married to a United States citizen is deemed an alien until she becomes a citizen of the United States by naturalization, and a non-resident until she establishes a home in the United States. I. T. 2600, X-2 Cunr. Bun. 107 (1931) ; T. D. 4316, X-1 Corr. Bulz. 99 (1931) ; T. D. 4301, IX-2 Cunr. Burc. 89 (1930).
} 
erty spouse, however, under the rule of the Cavanaugh case $^{46}$ may still split his community income. ${ }^{47}$

\section{Where there is a decree of divorce or of separate maintenance.}

The applicable "determination of status" sections ${ }^{48}$ provide that persons shall not be deemed married when living apart under a decree of divorce or of separate maintenance, and thus may not file joint returns. Where a divorce has been granted, non-community property and community property couples alike are precluded from filing a joint return. ${ }^{49}$ However, in absence of an agreement to the contrary, ${ }^{50}$ earnings during the interlocutory period are community income ${ }^{51}$ and

46 Commissioner v. Cavanaugh (C. C. A. 9th 1941) 125 F. (2d) 366. A husband living in California was allowed to file on only one-half of his (community) income despite the fact lis wife lived in Canada, had never been in California, and probably never would be.

47 This rule may not apply where the wife is the resident and the husband is the non-resident alien. In a recent Texas case (Payne v. Commissioner of Int. Rev., (1942) 1 T. C. 362, aff'd (C. C. A. 5th 1944) 141 F. (2d) 398) the court distinguished the Cavanaugh decision on the grounds that the wife left her marital domicile in Ohio and moved to Texas, and that the marital dounicile did not follow her. Her husband remained in Ohio, and since under the law of Texas the wife obtained no marital domicile there, her earnings were not community income. The Tax Court said: "Lest it be rejoined that California Law may differ from that of Texas, an examination will show that the latter's statutory system of community property applies oniy where Texas is the marital domicile." California has adopted the counmon law rule that the wife's domicile is that of her lusband. Estate of Wickes, (1900) 128 Cal. 270, 60 Pac. 867; Cax. Gov'T CoDE § 244(f); (1928) 1 So. CalIF. L. Rev. 359. And the trial court in the Cavanaugh case based its decision on this theory. (1940) 42 B.T.A. 1037. The Ninth Circuit Court, in affirming the result, however, did not adopt the marital domicile concept, but, speaking through Stephen, J. said: "The husband's earnings after marriage while domiciled in California are counmunity property, CrvIr CODE $\$ 164$, and residence of the wife is not required (citations omitted) the wife's interest in her husband's income being determined by the domicile where earned and not by the law of the matrimonial domicile." (Italics supplied.) If CIva CODE $\$ 164$ were also applied to the wife who left her matrimonial domicile and came to California, it would seem that her earnings would be community property. It appears, however, that the weight of authority is with the Texas case. RESTATEMENT, Conflict of Laws \$\$289, 290 (1934) ; de Funiak, Princtples of Communtty PropERTX $\S 92$ (2d ed. 1943) and cases cited therein.

48 INT. REv. CODE $\$ \S 23$ (aa) 6, 51 (b) (5) (B).

40 Although the tax court formerly held in Ethel Dunn v. Commissioner of Int. Rev., (1944) 3 T. C. 319, that an interlocutory decree did not dissolve the marriage bonds in California, the express intent shown in SEN. REP. No. 1013, 80th Cong., 2d Sess. 50, 52 (1948), that $23(\mathrm{aa}) 6$ and $51(\mathrm{~b})$ be construed uniformly with $23(\mathrm{k})$ will undoubtedly inean that an interlocutory decree in Califormia will preclude a joint return. $C f . \mathrm{I}$. T. 3761, 1945 Cuar. BuLL. 76.

50 A property settlement agreement has been interpreted to provide that the earnings of the spouses were to be their separate property. Sommerville v. Commissioner of Int. Rev. (C. C. A. 9th 1941) 123 F. (2d) 975.

51 Brown v. Brown (1915) 170 Cal. 1, 147 Pac. 1168 ; Hiltbrand v. Hiltbrand (1936) 13 Cal. App. (2d) 330, 56 P. (2d) 1292; Dunn v. Commissioner of Int. Rev. (1944) 3 T. C. 319. 
community couples may split this income until a final decree is rendered. ${ }^{\mathbf{2}}$

Similar commumity property advantages may also be available where a decree of separate maintenance has been rendered. Joint returns are banned by the Internal Revenue Code in these situations, but even though the California courts are compelled to divide the community property when support and nraintenance are awarded, ${ }^{53}$ the subsequent earnings of the husband may still be community property. ${ }^{54}$

The Revenue Act of 1948 also raises new considerations for the separate maintenance agreement cases where no court decree is sought or rendered. Formerly spouses who entered into separation agreements that divided the community deprived themselves of the right to split their income. ${ }^{55}$ In the future, however, couples who desire separation and complete dissolution of the community niay so agree, and yet continue to split their income on a joint return. ${ }^{56}$ And couples who are at present living apart under agreements that have destroyed the right to split community income may now split their incomes under a joint return. ${ }^{57}$

\section{After the death of one spouse.}

In order that a surviving spouse shall not be deprived of income splitting advantages during the year of the death of the other spouse, the Revenue Act of 1948 provides that the surviving spouse may file a joint return with the administrator of the deceased spouse's estate.

52 In view of the manifest non-tax factors calling for complete property settlements prior to a suit for divorce, Adams v. Adams (1947) 29 Cal. (2d) 621,177 P. (2d) 265, it may develop that the California high-bracket salary recipient who contemplates immediate remarriage should avoid the one-year interlocutory period, and subsequent loss of the right to split his income, by obtaining a Nevada divorce. A spouse earning $\$ 50,000$ per year (with no dependents) would lose approximately $\$ 6000$ in taxes if deprived of income splitting for only one year. It is doubted that the Commissioner would challenge the vahidity of such a divorce. G. C. M. 25250, 1947-2 CoMr. BuLL. 32.

53 Car. Crv. Code § 137. Blache v. Blache (1945) 69 Cal. App. (2d) 616, 160 P. (2d) 136.

54 Commumity property is defined as all property "acquired by Lusband and wife, or either, during marriage, when not acquired as the separate property of either." CAL. CIv. CODE \$ 687. The decree of separate maintenance does not dissolve the marriage, nor the community. Monroe v. Superior Court (1946) 29 Cal. (2d) 427, 170 P. (2d) 473; (1947) 35 Calif. L. Rev. 153; (1946) 20 So. CaIIF. L. Rev. 104; Chirgwin v. Chirgwin (1938) 26 Cal. App. (2d) 506, 79 P. (2d) 722 ; Nelson, Divorce ANd ANNulatent \$ 18.24 (2d ed. 1945). The Civil Code specifically excludes the earnings of a wife, while living separate, from the community property, CAI. Crv. CODE § 169. Thus it seems that since the husband's earnings are not specifically excluded, and the marriage has not been dissolved, Lis earnings are still community property.

55 O'Bryan v. Cominissioner of Int. Rev. (C. C. A. 9th 1945) 148 F. (2d) 456.

50 There is no requirement that husband and wife live together in order to file a joint return.

57 The practical problems of getting separated spouses together for tax savings agreements that entail joint and several liability may well be insurnountable. 
This right, however, is subject to the election of the administrator. ${ }^{68}$ Under the community property system community income received up to the time of the dissolution of the community by such death may be returned one-half by the surviving spouse. ${ }^{50}$ And though property acquired after this dissolution-by-death is not community property, ${ }^{\circ 0}$ it has been held that upon the death of the husband, income derived from community property in the hands of the Executor or Administrator during administration may be returned one-half by the surviving wife. ${ }^{61}$ Thus surviving spouses in California may obtain some of the income splitting advantages even if the Executor or Administrator of the deceased spouse's estate does not elect to file a joint return. ${ }^{02}$ This advantage has increased importance where the period of administration lasts for more than one year.

\section{SOME TECHNICAC ASPECTS OF THE JOINT RETURN}

\section{A. Filing.}

The joint return is available to couples who, married at the close of the taxable year, ${ }^{63}$ have the same taxable years ${ }^{\mathrm{ct}}$ and are not legally separated under a decree of divorce or a decree of separate maintenance. $^{05}$

In order to obtain the benefits of a joint return the husband and wife must make an election to so file. Such an election made in one taxable year has no binding effect as to any other taxable year, and the spouses may change in each successive year without securing the consent of the Commissioner. ${ }^{66}$ But once a separate or joint return is filed for any year the election to so file may be changed with respect to that year only prior to the expiration of the period for filing, for once that period has elapsed the election is deemed irrevocable. ${ }^{67} \mathrm{An}$

58 INT. Rev. Code $\$ 51$ (b) (4); see note 30 supra.

59 Estate of Henderson (1932) 128 Cal. App. 397, 17 P. (2d) 786.

G0 Estate of Nelson (1930) 104 Cal. App. 613, 286 Pac. 439.

01 Bishop v. Commissioner of Int. Rev. (C. C. A. 9th 1945) 152 F. (2d) 389; accord: G. C. M. 2500s, 1946-2 CuM. BuLL. 49.

$62 \mathrm{As}$ for the year of death only, this community property advantage is more apparent than real, for in most situations the administrator would be willing to assume the joint and several hability in order to obtain the numerous tax advantages of the joint return. Where the surviving spouse has a large separate income, or where the decedent spouse died early in the taxable year, there will be considerably more tax savings under the joint return than under separate returns.

63 Or who would have been so married but for the death of a spouse.

64 Or who would have had the same taxable years but for the death of a spouse.

65 INT. REv. CodE \$\$ 51(b) (5)(B), 23 (aa) 6.

GB O.D. 968, 5 CUM. BULC. 195 (1921).

67 Grant v. Rose (N. D. Ga. 1928) 24 F. (2d) 115, aff'd (C. C. A. 5th 1930) 39 F (2d) 340; Binder v. Welch (C. C. A. 9th 1939) 107 F. (2d) 812; I. T. 2535, IX-1 Cuns. BuLc. 125 (1930) ; Mim. 3859, X-1 Cun. Bull. 141 (1931); I. T. 3775, 1946-1 Cum. BurL. 77. 
extension of time for filing granted to one spouse on a joint return inures to both spouses. ${ }^{68}$

Husbands and wives who are eligible to use the joint return may file a short form joint return as long as both use this method. ${ }^{69}$

The signature of both husband and wife is required on the joint return. ${ }^{\text {To }}$ The statement in a return that it is or is not joint is not conclusive as to its character, ${ }^{71}$ and a return purportedly joint, but signed by only one spouse, may be deemed merely the separate return of the signing spouse. ${ }^{12}$ One spouse may sign a joint return as agent for the other spouse, but the authorization to so act must accompany the return. ${ }^{73}$ The Treasury Department anticipates much correspondence with taxpayers resulting from the failure of both spouses to sign their joint returns. ${ }^{T 4}$ This correspondence will probably be directed at obtaiming the missing signatures and thus removing all question as to the joint and several liability of the spouses. ${ }^{75}$

The filing of a separate or joint declaration of an estimated tax will not affect the right of husband and wife to file separate returns or a joint return. If husband and wife make a joint declaration and later file separate returns, the amounts paid on account of the estimated tax may be treated as payment on the liability of either spouse and may be apportioned between them in any way they desire. ${ }^{76}$

B. Treatment.

The basic tenet of the joint return is that, although there are two taxpayers, there is only one net income. ${ }^{7 T}$ The husband and wife are treated as a taxable unit. ${ }^{78}$ Thus the $15 \%$ deduction for charitable contributions applies to the aggregated adjusted gross income of the husband and wife, ${ }^{79}$ and medical expenses are allowed to the extent

ES O.D. 521, 2 CuMr. BuLL. 203 (1920). This rule does not apply where spouses file separate returns. I. T. 1702, II-1 Cuar. BuLL. 167 (1923).

09 INT. REv. CODE $\$ 23$ (aa) 4.

70 U. S. Treas. Reg. 111, \$29.51-1 (1943).

71 Anderson v. United States (C. C. A. 5th 1931) 48 F. (2d) 201; O. D. 960, 4 CuNs. BurL. 255 (1921); XIII-2 CuMr. BuLr. 141 (1934).

72 MerTeNs, op. cit. supra note 45, $\$ 47.07$; William W. Kellet (1945) 5 T. C. 608. A return was filed containing only the husband's income, signed by him alone, and on which no mention of the wife was made. The return was marked "joint return." Held, from all the surrounding circumstances, taxpayer had filed a separate return. $C f$. William Francis Horsting (1946) 5 T. C.M. 421.

73 INr. Rev. CoDE \$ 51 (c) ; U. S. Treas. Reg. 111, \$ 29.58-4 (1943).

74 Statement by Commissioner of Internal Revenue, George J. Schoenman, Hearings before Senate Finance Committee on $H$. R. 4790, 80th Cong., 2d Sess. 289 (1948).

${ }^{5} \mathrm{It}$ is probable that in the near future new regulations will clarify the question of signatures on jomt returns, such as the effect of failure by one spouse to sign.

76 INr. Rev. CodE § 58(c); U. S. Treas. Reg. 111, \$ 29.58-4 (1943).

77 SEN. Rep. No. 1013, 80th Cong., 2d Sess. 53 (1948).

78 U. S. Treas. Reg. 111, \$29.51-1 (1943) ; Taft v. Helvering (1940) 311 U. S. 195.

79 Taft v. Helvering, supra note 78 . On separate returns the $15 \%$ applies to the adjusted gross income of each. 
they exceed $5 \%$ of this aggregated adjusted gross income. Capital losses of either spouse may be offset against the capital gains of the other, and the deductions and exemptions of the spouses may be pooled. ${ }^{80}$ Since, however, there are two taxpayers reporting on the joint return, spouses who on separate returns would each be entitled to $\$ 5000$ exempt income from U. S. Savings Bonds issued prior to 1941 will not be limited to a single $\$ 5000$ exemption on filing a joint return. ${ }^{81}$ They may still take two full $\$ 5000$ exemptions. ${ }^{82}$

\section{Liability.}

The tax on a joint return is computed on the combined income of the spouses and the liability is joint and several. ${ }^{83}$ There is no apportionment of liability relative to contribution to income, and situations could arise where a spouse who contributed little or nothing might be assessed for the entire liability. ${ }^{84}$ Possible constitutional objections would be dispensed with on the grounds that taxpayers have no inherent right to file a joint return and that Congress may impose joint and several liability on the spouses as a reasonable condition to the privilege of so filing. ${ }^{85}$ To indicate an affirmative election, it is probable that the Commissioner will insist on the signature of both spouses. Although the signature of both spouses would normally be required to establish their joint and several liability, ${ }^{86}$ there are special situations in which liability has been imposed where there has been no sig. nature by the spouse or by an authorzed agent. In one instance, for example, the presence of a fraud precluded the taxpayer from pleading failure to sign as a defense. The wife did not sign, but having failed to file a return for her separate taxable income, she was not permitted to deny liability on the deficiency assessed against the joint return. ${ }^{87}$ And subsequent affirmance by a spouse who has failed to sign a joint return has been held sufficient to establish joint and several liability. ${ }^{88}$

The statute of limitations begins to run when the return is filed,

80 Sor. Op. 90, 4 Cum. Butr. 236 (1921).

81 U. S. Treas. Reg. 111, \$29.22(b) (4) -4 (1943).

82 Letter ruling dated Dec. 8, 1943.

83 INT. REv. CODE $§ 51(\mathrm{~b})$.

84 Moore v. United States (Ct. Cl. 1941) 37 F. Supp. 136; Note (1942) 55 Harv. L. REv. 145; MERTENS, op. cit. sikpra note $45, \S 47.0$. The situation contemplated is one where shortly after a joint return the spouses are divorced, and the wife, being deemed the better prospect for tax collection, is assessed for the entire amount even thougb she contributed nothing to the earnings which were taxed.

85 MERTENs, op. cit. supra note $45, \S 47.0$.

86 William W. Kellet, William Francis Horsting, botb supra note 72.

87 Joseph Carroro (1933) 29 B.T.A. 646. Where a busband filed a joint return without objection of the wife who failed to file a separate return, it was presumed that the joint return was filed with the tacit consent of the wife. The burden of proof to show that the return was not joint was on the wife. Myrna S. Howell (1948) 10 T. C. No. 115.

88 Frank A. Weinstein (1935) 33 B.T.A. 105. But see Crowe v. Commissioner of Int. Rev. (C. C.A. 7th 1936) 86 F. (2d) 796. 
and will run as to both spouses on a joint return even though only one has signed. ${ }^{89}$

When a deficiency is assessed on a joint return, the Commissioner may send a single joint notice of deficiency to spouses unless he has received notice that they have established separate residences. If he has received such notice, the Commissioner must send duplicate originals of the joint notice to each spouse at his last known address. ${ }^{90}$

Since the liability of the spouses is joint and several there is a possibility that a gift tax may be inposed on the spouse who individually pays the entire tax. For example, where each spouse has a separate income of $\$ 20,000$, on separate returns each would be liable for approximately $\$ 6500$ in taxes. On filing a joint return, the total tax liability would be the same, but it would be a joint and several liability. Thus if the husband pays the entire tax, he has in effect made a gift to the wife in the amount of her tax liability.

A similar problein was specifically covered in the Senate Report on the gift tax amendments. ${ }^{91}$ This report states that there will be no gift tax imposed on the spouse who may satisfy the joint and several liability of the spouses mcurred from a gift of family property ${ }^{92}$ This same attitude should be applied in the parallel income tax situation mentioned above, but since it was not specifically covered it is open to the construction that a gift tax was intended on such transactions.

\section{Refunds.}

In view of the fact that claims for refunds, defective in form, can be dismissed by the Commissioner even though they contain substantive merit, ${ }^{93}$ it is important that the taxpayer comply with all procedural requirements. Substantially all of the forms provided by the Treasury Department for use im refund proceedings require the signatures of both spouses if they have filed a joint return. Refund suits brought in the District Court and in the Court of Claims should be in the name of the husband and wife. A similar rule applies with respect to petitions to the Tax Court. ${ }^{94}$ Furthermore, if the proceeding is brought in a representative capacity, such authority to represent must be shown..$^{85}$

If separate returns are filed one spouse has no claim to refunds

89 Mrs. Sidney Smith (1926) 4 B.T.A. 385; Mrs. W. H. Turner (1927) 5 B. T. A. 1206; G. C. M. 13705, XIII-2 Cuar. BULL. 141 (1934).

90 INT. Rev. CoDE $\$ 272$ (a) 1. Notice to the Commissioner regarding separate residences should he addressed to the Commissioner of Internal Revenue, Washington, D.C., for attention of the Income Tax Unit, Record Division.

01 Sen. Rep. No. 1013, Pt. 2, 80th Cong., 2d Sess. 35 (1948).

92 INT. REv. Code $\S 1000$ (f) (4).

${ }^{93}$ Angelus Milling Co. v. Nunan (1944) 325 U. S. 293; (1945) 1 TAX L. REv. 45.

94 Ethel Weisser (1935) 32 B.T. A. 755.

95 Leesa Dombrowski (1937) 35 B. T. A. 1028. 
properly made to the other spouse, ${ }^{98}$ but where joint returns have been filed the Commissioner may properly apportion the refunds to the individual spouses. $\mathscr{}$

\section{E. The Effect of a Change in Form of Filing on Loss Carry-overs and Carry-backs.}

In view of the fact that spouses may change from joint or separate returns to separate or joint returns without permission of the Commission ${ }^{98}$ there may be a tendency to change form wherever a tax saving will be realized. This change may prove impractical where a capital loss carry-over or a net operating loss carry-back and carryover is involved, since highly complicated accounting problems may arise.

There is little difficulty in the change from separate to joint return, for the prior individual net capital loss carry-over or the net operating loss carry-back and carry-over are merely aggregated to ascertain the joint capital loss carry-over or joint net operating loss carry-back and carry-over. ${ }^{99}$

Where there is a change from joint return to separate returns, computation becomes more difficult. To compute separate net capital loss carry-overs from a joint net capital loss carry-over, the net capital loss as shown by the joint return for the five preceding years must be allocated to the spouses on the basis of their individual net capital losses for each such preceding taxable year. The net capital loss so allocated is then treated as a short term capital loss carry-over on the respective separate returns. ${ }^{100}$ The Regulations outline the detailed procedure for computing separate net operating loss carry-back and carry-over from the joint net operating loss carry-back and carryover. In general, the income, deductions, and net losses attributable to the respective spouses for the years in question must be allocated to the spouses, and the net loss carry-back and carry-over is recomputed for those years as if separate returns had been filed. ${ }^{101}$

\section{CONCLUSION}

With the enactment of the Revenue Act of 1948, and the extension of income splitting to married couples throughout the nation, substantial income tax equality has at last been achieved between community property and non-community property couples. However, since community property couples now have two possible methods for splitting

96 Marshall v. United States (S. D. Cal. 1939) 26 F. Supp. 580.

97 Lattimore v. United States (Ct. Cl. 1935) 12 F. Supp. 895.

08 O. D. 968,5 Cum. BuLc. 195 (1921).

09 U.S. Treas. Reg. 111, § 29.117-5(a) (b), 29.122-4(e) (1943).

100 INT. REv. CODE $\$ 117$ (e) (1).

101 U. S. Treas. Reg. 111, § 29.122-4(e) (1943). 